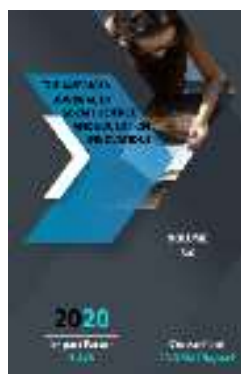

\title{
The Work Of Sohfi Allahyar "Sabot UI - Ojizin" Is In Harmony With Today's Times
}

\author{
Khimmatova Zarina Akhtamovna \\ Doctoral Student Of The Department Of Philosophy And National Idea Faculty Of Law \\ Samarkand State University, Samarkand, Uzbekistan
}

\begin{abstract}
Journal Website: http://usajournalshub.c om/index,php/tajssei

Copyright: Original content from this work may be used under the terms of the creative commons attributes 4.0 licence.
\end{abstract}

\section{ABSTRACT}

The article analyzes the solidarity of "Sabot ul - ojizin's" work with the present period, which took an important place in the history of Uzbek enlightenment in the second half of the XVII century and the beginning of the XVIII century in Central Asia, the major representative of the Naqshbandian sect, Sofi Allahyar's "Sabot ul - ojizin". The work of sohfi Allahyar "Sabot ul - ojizin" is a work created due to the spiritual need of his time. The main purpose of the creation of the work is to educate the perfect person, to strive for the perfection of the individual. It is up to the people to start them on the right path by revealing the Enlightenment of the Islamic religion, to encourage them not to fall under the influence of the ideas of the memorization of different currents and fanatic groups. In the article, the work studied the socio - philosophical views aimed at starting the people on the right path, and in turn revealed that at that time for material benefit, he was struggling with enlightenment, occupying the minds of the common people and distributing various superstitious teachings. The article analyzes the ideas put forward in the work" Sabot ul - ojizin", the philosophical views, the solidarity of such enlightened views as leading the people towards perfection with today's times.

\section{KEYWORDS}

Sohfi Allahyar, "Sabot ul - ojizin" spiritual need, striving for perfection, the educational aspect of Islamic religion, creed, superstition, struggle with Enlightenment against ignorance, change people's consciousness, solidarity with today's times.

\section{INTRODUCTION}

It is known from history that the scientific and religious, philosophical and spiritual views of the thinkers of Central Asia had a positive impact on the development of world civilization and human thinking. Because the great thinker leads mankind towards 
perfection, philosophical - humanistic views, religious - educational ideas put forward in the works of our ancestors. He calls on the person to be perfectly educated, to be spiritually harmonious and moral, to be a nationalist, patriot. Although their literary and spiritual heritage was created many centuries ago, it has not lost its relevance even for today's times, but on the contrary is in harmony with the times in any society.

Studying the spiritual heritage left by them in a thoughtful and unbiased way, applying it to life, educating the younger generation as worthy of ancestors is the destiny of the era. In this regard, the president of mukhtaram Shavkat Mirziyoyev expressed the following opinion:"... even if there is a leaflet related to our history, culture and religion, it is to gather them together and introduce our people and young people, to mean what a great and unique heritage we have, to educate our children worthy of this glorious nation." [1]

Specific awakening in the Eastern countries (Renessans) period in the history of the peoples of Central Asia cultural-spiritual rise, it is no accident that it is determined by renewal in the style of contemplationit is not. After all, the contribution of philosophical and scientific ideas of our great ancestors to the development of human thinking was great. [ 2.139]

Among such great ancestors, the second half of the XVII century, the first half of the XVIII century, the poet Sufi Allahyar, the scientist of theology, faqih, zullisonayn, who lived and worked there.

\section{MATERIALS AND METHODS}

Sufi Allahyar literature and spiritual heritage has a special significance in the history of Uzbek classical literature, mysticism and Uzbek enlightenment. He created four major works in the philosophical-moral-pedagogical, literarydidactic direction. They are: "maslak ul- muttaqin" and "Murad ul-orifin" in PersianTajik, "sabot ul-ojizin" in Turkish-Uzbek and "Mahzan ul-mute'in"in Arabic.

After his work " maslak ul-muttaqin "became popular among the Persian-speaking community, the Turkic-speaking people also wanted to be such a work in their own language, thus creating the work" sabot ulojizin " of the so-called Allahyar. [3.30]

Sohfi Allahyar: written in Persian, the letter refers to his work "maslak ul-muttaqin" in Egypt. There were few works, explaining the Sharia rules, requirements in Persian and Turkic languages, until the Sufi Allahyar. But among the Persian and Turkic-speaking peoples who accepted Islam, the spiritual need for such works was very strong.

Taking into account this, Sufi Allahyar originally created the work "maslak ul-Muttaqin", consisting of eight hundred pages in the Persian language, which quickly became popular among the el. After that, the hormones of the Turkic-Uzbek people to such a work in their own language became stronger.

The main goal of the creation of Sabot ul-ojizin is the upbringing of a perfect person. The topics covered in it encourage a person to be morally pure, spiritually harmonious, to work honestly, to practice family medicine, to avoid taste. And this is no doubt that it does not lose its relevance in any period.

So this work is a work created because of the spiritual need of its time. This work is not an exaggeration if we say duru Javakhir, who enriched the treasure of Islamic Enlightenment, made a huge contribution to the rise of our spirituality. The role of this book in the education of generations for more than three hundred years shows that this book has been taught as a textbook and a guide in school madrasahs. 
The work of Sabot ul-ojizin has been published many times in the countries of Central Asia, Pakistan, India, Iran, Iraq, Afghanistan, Tatarstan, Saudi Arabia, Egypt, Turkey, China, Vengria, Russia and other countries.

In Uzbekistan, it was published in Tashkent in 1882, 1884, 1905, 1915 in Kogon in 1910, in Kogon in 1890, in Tashkent in 1991, in 2007. Since Arabic, Persian words are often used in the style and language of the statement of this work, so many reviews have been written to make it clear to readers.

One of the most urgent issues of the work is to reveal to the people the educational aspect of the Islamic religion, to start their path, to urge them not to join different groups of currents and fanatics. This topical issue is in line with today's era. If we look at the spiritual environment of the time when the Sufi Allahyar lived, first of all, he began to grow in the Indian region of its base centers by attaining the position in Central Asia from the second half of the XVI century of the Naqshbandian sect, which belonged to him, [4. 84] the reason lies in the turbulence, instability in the socio political life of Movoraunnahr, the desire of sectarian piracy to seize power, the link between the slaughter of educational affairs among the people. Especially by the XVII century, the principle of striving for political power took precedence over the leadership of the sect among the descendants of the Naqshbandiya sect piri Mahdum. [5. 55]

It was customary for the priors of the sect to strive for the circle of the Huns, to try to capture large foundations and collect property. As a result, many independent rings were formed on the territory of Movarounnahr, resulting in regional borders and mutual competition.

The development of Naqshbandiya after the $\mathrm{XVI}$ century is associated with India. Bakibillah Berang founded the Nakshbandiya Center in Delhi and in a short time managed to spread his teachings throughout India. [6. 17] here it is possible to see that later the ornament fell under the influence of various sects, beliefs and philosophical views. During these periods, countless categories of interrogations appeared in India and Turkey, various methods and teachings that encourage the acquisition of Sufism career status through the promotion of law, painting. No sect in India could be ruled out from the influence of the surrounding religious environment, many industries began to absorb and falsify the ideas of various superstitious doctrines and contradictory currents. [7. 87] Of course, these teachings, developed on the outskirts of Movarounnahr, did not exert their influence on the social spiritual life. Because Movarounnahr had trade and common migratory territory with China, Afghanistan, Iran, India and Turkey .

The reason for the above events began to enter into various yacht ideologies, superstitious vices from the Indian, Iranian, Turkish regions to the territory of Central Asia. As a result, the people became rich from the true Islamic Enlightenment and began to be mistaken as they perceived 14 superstitious teachings as the "way of their ancestors". In order to gain material wealth, various religious currents and fanatical groups were formed and began to mislead the common people on the right path.

\section{RESULTS}

Not indifferent to such spiritual degradation, Sofi Allahyar intended to open the essence of true Islamic Enlightenment in his works to the common people and begin the right path. And this goal never retreated in a lump.

In the work of sohfi Allahyar "Sabot ul-ojizin", 14 bio-teachings were widely discussed at that time. [7, 137-138] by exposing their original work, he struggles "against ignorance-with enlightenment", knowing well that it is his duty to warn the people before Vatan. That is, the most optimal way to put the people on the 
right path was to put their faith on the right path through their works, the most optimal way to put their faith on the right path through their works. On this path, The Thinker decided to spend his life among the people. In a certain biography, it is also known to us that it was passed among the nomadic Turkic tribes living in the cities and villages of Bukhara, Samarkand, in the steppes of Kashkadarya and Surkhandarya. That was the purpose of writing the work "Sabot ul-ojizin" in Uzbek. This work had a simple, simple language and an impressive spirit that quickly and efficiently influenced people's ideology. They entered into each apartment as a specific band reminder, a program for the education of young people, an instruction manual. [3. 39]

The Adib calls for the study of the science of enlightenment and says that hell is the place of man who is left untouched by this science, that is, the familiar knowledge of Allah.

In the work of Sabot ul-ojizin it is possible to observe that the people of Sohfi Allahyar fought in two directions not to fall under the influence of different yacht ideas and ideologies. While the first stage was the stage of calling for purification, purification of the people, the second was the stage of morality and enlightenment education. As a result of the first stage, Bunda was able to enlighten the enlightened nation, to bring a conscious, intelligent, individual to perfection, able to adequately confront destructive ideologies with knowledge and enlightenment. The Thinker did not retreat from this path at all, and remained, in his own eyes, "indifference to the life of society is a trick," he told the people to be responsible for the fate of Motherland, to understand that every citizen has a duty to society. This vision and Idea, in turn, since the first years of our independence, until now, is in line with such a rational policy as the struggle against ignorance - Enlightenment, which is carried out by our government, the duty of every citizen to recognize the responsibility of "inviolability "to the fate of society.
Another topical issue of Sabat ul-ojizin is that when starting the right path, young people who have fallen under the influence of yacht ideas, who are being sacrificed in the interests of the holidaymakers, it is necessary to refuse all from one side and act. In his opinion: "not knowingly showing the way to the person who has gone astray, not trying to start the right way, is a betrayal of society. Directly in this regard, the president of mukhtaram Shavkat Mirziyoyev expressed the following opinion: "the misdirection of one child is not only a family, but also a suffering for the whole society. No person living in our country, thinking about his family, children, tomorrow, representatives of the public of religious figures should not be excluded from this - the issue of life."[ 1 ]

The religious and philosophical views of sohf Allahyar, which he put forward many centuries ago, are on the most pressing issues and are in harmony with the Times. Proof of this is reflected in the above-mentioned ideas and views of the thinker.

\section{CONCLUSION}

In conclusion, the most prominent citizen of the XVII - XVIII century, the people's poet, the people's poet, was a self-sufficient person. Not only did he create a work for khoyu-Khawas, but he, as a true patriot, Fidai child of our people, embodied in his works his ideas and philosophical views, encouraged the people to be enlightened, to be educated, to build the way of life on the basis of honesty and purity of each person. He called on citizens not to be indifferent to their community, but young people to be patriots. The highest goal of Sohfi Allahyar was to change people's consciousness.

The fact that the people have both religious and secular knowledge has shown through their works that it plays an important role in the development of society. 
The philosophical views of the Sufi Godhead were reflected in his works and were in harmony with today's times. It is without doubt that his works have a program - practice in educating the younger generation in the spirit of patriotism.

\section{REFERENCES}

1. President of the Republic Of Uzbekistan Sh.M.Mirziyoev's speech at the conference on "Ensuring social stability, preserving the purity of our sacred religion - mad of the era". 15.06.2017 y. // uza.uz / politics / homeland - alive - and - kelazhagi - y lida - further - am - zhi - at - b - lib. 15.06.2017 y

2. Sultanova Gulnoza. Science in the hadiths: history and times. Volume 1 Issue 2 Oriental Studies. №2 2019. 5-272019. - P. 137-145.

3. Rashid Zahid. Sofi Allahyar. "Sabot ulojizin", comment. Ravayihor Reyhan. T : "East", 2018-48ob. -P. 30-33-39.

4. Trimingham J. Sufi orders in Islam / Trans.eng. Stavisky and under. Ed. O. Akimushkin. Moskva, 1989, -pp. 84-87.

5. Kattaev K. "Mahdumi member and Dahbed". Samarkand, 1994, B-55.

6. Abdullaev I. Bahouddin Patternband / set of lights lit from the winner's Hoyle. Tashkent, "Uzbekistan", 1994, -P.172.

7. Sirajiddinav Sh. "Sohfi Olloyor divine" Part I of publishing house of Imam Al Bukhari International Foundation, Tashkent 2001, -P.80.

8. Son of Tojiddin Yolchigul. Risalai Aziza. Print, Cazan, 1880, $\quad$-P. 137138. 